\title{
Discovering a 'post-revolutionary' sense of place in China's small commodity city of Yiwu
}

\section{Introduction}

A three-hour train journey inland from Shanghai, along the Yangtze River Delta (YRD), lies the city of Yiwu. Its existence stretches back to the Tang dynasty (618-907) and promotional websites point to its famous residents from the Tang (618-907), Song (960-1279) and Yuan (1271-1368) dynasties, as well as more recent prodigies such as the educationalist Chen Wangdao, the literary theorist Feng Xuefeng and the historian Wu Han. However, there are few signs of this dynastic history today, save for an old pagoda that stands by the man-made lake, which is itself strangely juxtaposed against the high-rise apartments. What was once the village of Yiwu has expanded rapidly over the past three decades, increasing its city centre ground area to 90 square kilometres and re-branding itself around its 'small commodities city' status, which was granted by the Chinese government in 1982 in recognition of its specialism in small, low-end consumer goods. Since that time, it has used its small manufacturing economy to transform itself from a traditional agricultural town to the key driver of a huge regional economy, not only in Zhejiang province, but in the YRD economic area1 as a whole (Chen 2000). As a result, it has become a key destination for international wholesale buyers of low-end products. This expansion was greatly aided in 1984 by the famous ' $n$ 4 document', which entitled private Town and Village Enterprises (TVEs) to the same tax incentives as collectively-owned TVEs, and the same policy treatment as State Owned Enterprises (SOEs). These changes effectively equated private firms with SOEs and their impact on potential private entrepreneurs was huge. According to Huang $(2008,97)$, within one month of its announcement rural residents in the county of Yiwu raised 10 million yuan and established 500 businesses.

Today, Yiwu has a population of 2.2 million residents and a daily customer flow volume of more than 210,000 . It contains more than 800,000 private companies, the vast majority of which are small family-owned enterprises that manufacture small, inexpensive commodities such as socks, toothbrushes, plastic cups and cheap ornaments. The city's layout is organised around its immense commodity market buildings, each one containing within it smaller markets that specialise in specific product areas. Each market's floors are divided into aisles made up of identically-sized small square display stalls, ordered in sections according to the type of commodity on display, and each one displaying the wares of one company (see Figure 1). Together, these markets cover an area of approximately 2 million square metres, containing around 58,000 company booths. On average, more than 1500 containers of goods leave Yiwu every day, largely bound for Europe and the US. 2

Figure 1 Inside one of Yiwu's commodity markets. Photo: author's own. 


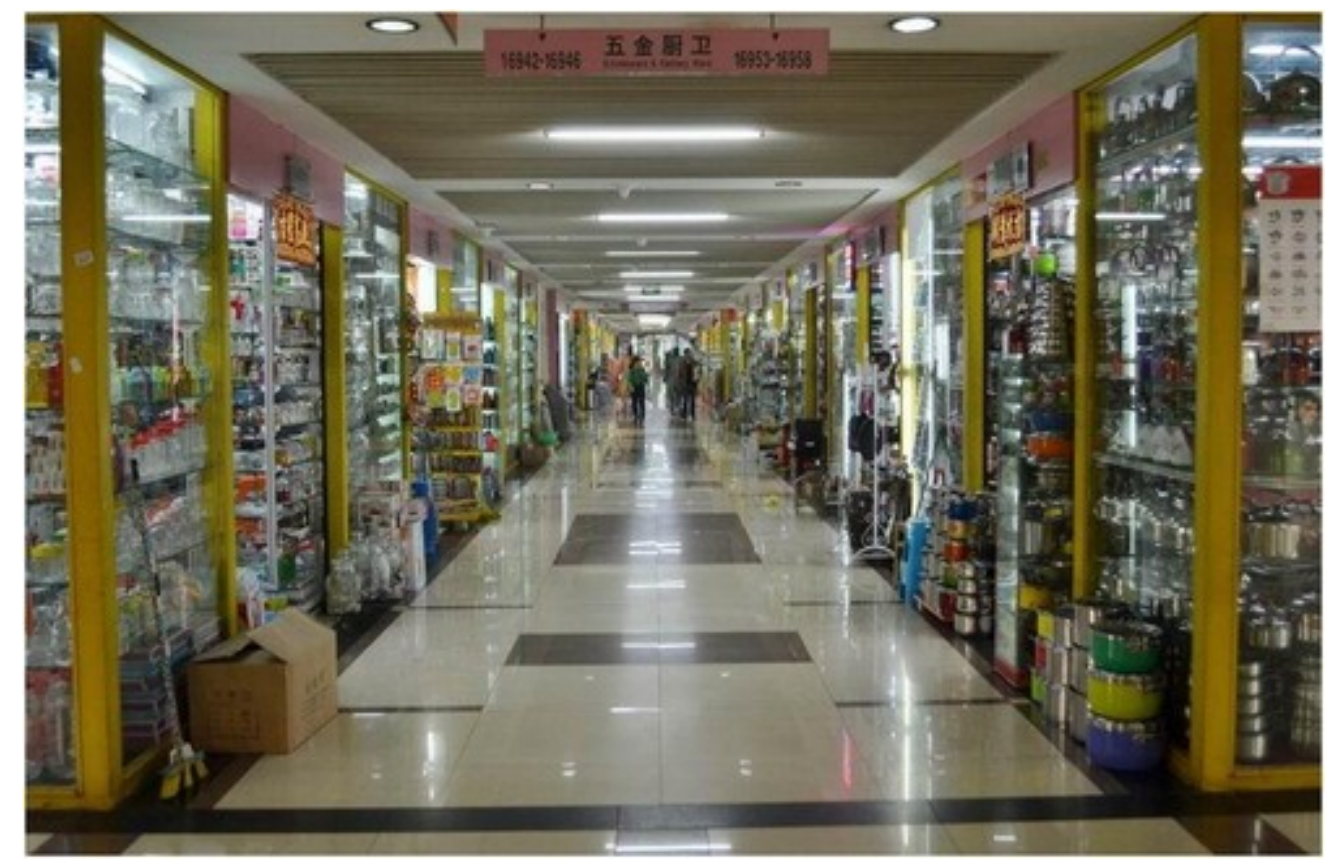

This article takes the city of Yiwu as a case study that enables an analysis of Chinese cities beyond the usual well-known cosmopolitan examples of Beijing and Shanghai. In doing so, it furthers the existing literature on urban China and small cities. However, its wider aim is to use Yiwu as a case study by which to explore thinking on place, challenging Marc Augé's conception of place as geographically bounded and based on collective memory (1995) and exploring place as more akin to what Doreen Massey has called 'articulated moments in networks of social relations' $(1991,27)$. In other words, to discuss place not as a coherent and stable physical and emotional entity, but rather as a moment in time in which people and things (past and present) mesh in an unusual way. Massey argues that one of the results of a world in which globalisation and advances in technology have created time-spacecompression, is an increasing uncertainty about what is meant by the term 'place', and a concern that any sense of place might be lost. However, she goes on to assert that the framing of such questions relies upon a dubious counter-positioning of 'an (idealised) notion of an era when places were (supposedly) inhabited by coherent and homogeneous communities', against 'current fragmentation and disruption' (1991, 24). This counterposition is dubious because in her view 'place' and 'community' have hardly ever been coterminous, and the longing for 'coherence' when it comes to place has sometimes given rise to reactionary responses such as nationalism and antagonism to 'newcomers' and 'outsiders' (1991, 24).

However, Massey does not want the seeking of place to be seen as necessarily reactionary, suggesting that it is not so much the concept of place that is problematic in and of itself (as it is understandable for people to seek attachment), but rather the way in which place is conceptualised, and the notion of it as geographically specific and stable $(1991,24)$. What Massey seeks, is an outward-looking, non-reactionary sense of place that is 'adequate to this era of time-space-compression' $(1991,24)$. This 'progressive' sense of place entails specific features. It is not static, but rather, conceived of in terms of its social interactions; it does not have boundaries in the sense of divisions which frame enclosures; is does not have a single, unique identity, but rather, contains various internal conflicts, such as over the area's heritage, for example; and finally, its specificity and uniqueness do not result from a long, internalised history (1991, 28-29). 
In light of Massey's assertions above, this article takes the city of Yiwu and attempts to rethink place via an analysis of an economic model (the Wenzhou model, which is explained below), as well as a built form (the 'small district' or xiaoqu). It argues that the use of the Wenzhou model in Yiwu situates it at the forefront of a national historical economic trajectory, and that the development of small districts, tied as they are to previous historical built forms, provides a sense of the past as an assemblage from which current postrevolutionary identity can be forged. The discussion of Yiwu here is informed by four months of fieldwork conducted in 2014 during which the author shadowed eight wholesale buyers as they engaged with manufacturers in the markets, and conducted ad-hoc informal interviews with 22 resident manufacturers, both in the markets and in local cafes, enabling insights into the ways that residents perceived and connected with their city. 3

The cultural legacy of the Wenzhou model: making, breaking and re-making an economic paradigm. The city of Yiwu operates almost entirely according to the famous Wenzhou model, a mode of commercial organisation that is historically specific to Wenzhou city, in south-east Zhejiang province. The model has existed for centuries despite struggling to be accepted. It is characterised by four key features: (1) it consists of numerous small-scale private enterprises; (2) it specialises in wholesale petty commodity markets; (3) it is built on tens of thousands of mobile traders who facilitate the flow of materials; (4) it is made possible by various forms of non-governmental financial arrangements (Liu 1992). The nature of these operations means that the Wenzhou model works to maintain low costs in return for low profit margins, which in turn means scale is required in order for the low profit margin per unit to still deliver economic viability overall. Therefore, typically, the Wenzhou model relies on small family businesses, making low-value products, in great numbers-the many small parts that the famous businessman Jack Ma describes as 'shrimps, not whales'.4

Most accounts of the Wenzhou model agree that its origins lie in the Southern Song dynasty (1127-1279), specifically the point at which Yonjia county (in which Wenzhou is situated) in Zhejiang province started to drift from the mainstream of neo5-Confucian thought and set up the Yonjia School. It has been argued that it is the figure of Ye Shi (1150-1223) who is instrumental here (Yu, Zhou, and Jiang 2012). He is known for having systematically refuted many key ideas within the mainstream ideology of the time, such as giving high priority to justice and low priority to profit, restraining material gains by promoting justice and reason, and giving high priority to agriculture and low priority to commerce. Instead, he promoted the idea that profit and the spread of wealth was integral to justice in society and that therefore, traders ought to be perceived as the backbone of society. For him, letting people get rich was the fundamental way in which a state could be governed-a sentiment that would famously be echoed by Deng Xiao-ping6 (2012, 45-46). Such thinking became very important across the region and therefore, unlike other provinces, Wenzhou tended to celebrate commercialism. Furthermore, Ye Shi's influence extended to later thinkers from Zhejiang province, such as Wang Shouren and Huang Zongxi, who became the most important philosophers of the Ming and Qing dynasties respectively, insuring the enduring appeal of Wenzhou's operations. As Yu argues, 'the emergence of the Wenzhou model ... was an inevitable reflection of that culture' $(2012,45)$.

The Wenzhou model was always viewed with suspicion under Confucianism. However, under Mao it was deemed wholly offensive and was banned even before full collectivisation began to take place. Under Maoist logic the model was deemed to be particularly capitalistic in nature, due to its reliance upon the individualistic motivations that underpinned small-scale entrepreneurship (i.e. at the level of the family unit). Mao's specific concern with this smallscale model was born out of his strong belief in collectivisation-itself a product of his adherence to the Leninist policies that China followed until the mid-1950s. Yet, despite these challenges the model persisted, largely because of Wenzhou's geographic isolation and 
distance from Beijing - there is a saying in Wenzhou, 'the mountains are high and the emperor is far away'.

Following the inauguration of Deng Xiao-ping as leader in 1978, the newly initiated reform and the policies aimed at opening up China to the world saw Wenzhou become the first city to set up private enterprises and shareholder cooperatives, largely because it had remained more commercially minded than other parts of China. Such enterprises were enabled due to the reforms carried out in Wenzhou's financial system and structure, and the development of a commodity economy very soon after the reform era began. This economy was based on household industries and specialised markets and fitted the new national rhetoric of creating individual entrepreneurs of all Chinese citizens. Deng's re-appropriation of neo-

Confucianism at the time encouraged intra-family lending and the promotion of family businesses, under the guise of familial loyalty and taking personal responsibility for one's well-being. However, as the Wenzhou model began to gain clout and acceptance during the 1980s, it also became criticised nationally (and to some extent internationally) for certain aspects of its operations, such as its use of informal lending and child labour. So, despite the fact that the further development of 'market socialism' over the 1990s saw the Wenzhou model become the official economic paradigm model for China, Deng Xiao-ping also recognised that in its 'unofficial' forms, this paradigm did not suit the new ordered, 'civilised' look that China wanted to promote to the West-a look that was of course also instrumental in reassuring the domestic population that post-Mao policies were desirable.7 As a direct result, the markets that Wenzhou migrants set up in certain quarters of large cities were cleared time and time again, and were eventually razed, thus pushing many migrants to return to Wenzhou.8

The presence of the Wenzhou model in Yiwu however, is an essential part of its identity for many of its workers and residents. Manufacturers are extremely aware of the city's specific mode of operating, and the ways in which this has contributed to its economic status and success. Many of those encountered as part of this research praise the Wenzhou model and are keen to point out that 'without Wenzhou China would be nothing', and that 'small commodities need the Wenzhou way of working'. Similarly, connections are made between 'Made in China' and Wenzhou, with manufacturers showing awareness of the way in which China is globally known for low-end products and how this has been the key to the country's economic success. Some even feel China would not have been able to develop as quickly as it has without the Wenzhou model, and all see Yiwu as the shining example of the Wenzhou model—it is an intrinsic part of the city's identity.

The cosmetic changes initially made to the Wenzhou model (through the razing of markets, for instance) were rooted in the presentation of market efficiency, whereas the main flow of urban change in China in more recent years has been far more concerned with creating what Bella Dicks calls 'visitability' $(2004,199)$-touristic places and events that will attract foreign and domestic leisure visitors.9 Kendall (2015) examines the dilemma that this tendency poses for smaller cities that can neither promote themselves as 'world cities', or as rural idylls. His case study of Kaili, in Guizhou province, explores how the small city exists in a complex relationship with the big city and the village, "pulled towards large-scale urbanization while simultaneously attempting to construct a unique city image based upon the evocation of rural cultural practices' $(2015,665)$. He argues that Kaili tries to satiate the demands of big city tourists for rural authenticity, but that authorities there also have a strong desire to climb the domestic administrative hierarchy of cities via urbanisation. This means that cities such as Kaili defy the typical core-periphery logic whereby peripheral cities attempt to emulate core cities in order to accelerate their economic development, as they also rely upon the rural imagery that is part of their identity as peripheral cities when branding themselves $(2015,676)$. Yiwu is no exception to this. On the one hand, the infrastructure, the abundance of commodities, and the fact that on the one hand, the city's overall efficiency is what is celebrated. On the other, aspects such as past literary masters 
and philosophers, the ancient pagoda, and the amount of square metres of green urban space per resident are highly promoted. Whilst Yiwu was, to all extents and purposes, developed as an acceptable version of the Wenzhou model and many migrant traders were encouraged to go there, it is branded as a strange mixture of contemporary green efficiency-or 'oxymoronic urbanism', as Jung (2014) calls it - and ancient village backwater, just as the city of Kaili is, according to Kendall (2015).

It is worth exploring this 'oxymoronic urbanism' in slightly more length here. Jung draws upon New Songdo City in South Korea, as well as Yujiapu and Lingang in China, as examples of newly developed cities that draw upon the Global City paradigm, by employing a competitive developmental agenda that consists of both 'catching up with the West' and 'surpassing regional rival cities' (Jung 2014, 329). He argues that these two paradigms are emblematic of how planning discourses based on ecological consciousness and technologically advanced urbanism now dominate city development. Under this ideal, new cities are supposed to engender 'an environmental and economic equilibrium in which the ideal city forms an enclosure, a city of social harmony with low consumption of energy and natural resources' (Jung 2014, 329). As Jung argues, this requires a mixture of pre and postindustrial imaginations consisting of an idealised appearance of the city that relates to a time before urbanisation, and an advanced service economy that is free from pollution (Jung 2014,329 ). This combination is the imagination of 'pastoral modernity', or 'oxymoronic urbanism' that Jung refers to.

However, alongside these twin concerns of pre and post-industrial imaginations, Jung argues that oxymoronic urbanism also has at its core a promise of progress with decidedly nationalistic tendencies. He argues that this 'progress' often defines itself in comparison to 'the West' (mainly via Western living standards) can be seen as a state technique for nationbuilding that is specifically concerned with catching up with the West $(2014,349)$. Ananya Roy's position is useful in light of this argument, as she posits that urbanisation in Asia is part of a post-colonial 'worldliness' that operates in the name of Reason, in order to seek a place for the nation in the global order of capital. In this way, new cities become a specifically post-colonial response to the perceived emergency of national survival (Roy and Aihwa 2011, 322). Whilst it is not a global city and does not try to be in the traditional sense, these comments are interesting when applied to Yiwu. It certainly has aspects of both ecological consciousness (the square metres of green space per resident, for example) and technologically advanced urbanism (such as the well-developed infrastructure and efficiency) and is promoted as important both regionally and nationally. Furthermore, its presence as a shining example of the Wenzhou model that delivers economic success both regionally and nationally very much fits the nationalistic development paradigm. Therefore, due largely to its historical connections to the Wenzhou model, Yiwu could be described as using oxymoronic urbanism in a specifically strategic way that operates on regional, national, and global scales, in order to further China's economic development as effectively as it can. The following section shows how this strategy is reflected, not only through a celebration of, and engagement with the Wenzhou model, but in Yiwu's built environment.

The importance of the 'small district'-an indication of 'post-revolutionary' subjectivity? Alongside its application of the Wenzhou model, and adherence to trends in 'green' planning, Yiwu's built environment is another of its defining elements. Its lay-out transparently reflects its manufacturing raison d'être, with all of the main roads heading towards a commodity market. The way in which key elements of a city (housing, leisure, education, and so on) are positioned around massive wholesale commodity markets, with access to key transportation infrastructure, has become a specifically recognised planning model transportable outside of national borders. Indeed, the first 'copycat Yiwu' was opened in Warsaw, Poland, in 1992, having been established by the local government of Guangdong, China. Following this, in 2003 a joint venture between an Austrian and a Chinese businessman saw the opening of the AsiaCenter in Budapest. Then, in 2004, a 
Chinese government agency-Chinamex - created the 'Dragon Mart' centre in Dubai. Agreements for a further centre to be situated at Schiphol airport area in Amsterdam were signed in 2007. Most recently, the Chinese company Fanerdun Ltd proposed a copycat market in Kalmar, Sweden.

However, despite the functionality of planning in Yiwu, its housing and production areas are not simply dictated by their position in relation to a commodity market. They also follow a different logic which appears unable to escape various older spatial repertoires, and which is bound up with past cultural movements and historical change in China. Like many 'new towns' in China, Yiwu was built based on the concept of 'small districts' (xiaoqu) - a term best understood as planned neighbourhoods in which housing is integrated with communal facilities such as nurseries, clinics, restaurants, shops, and sports facilities. As Lu (2006) illustrates, small districts have been influenced by various historical built forms including Western neighbourhood models, radical Soviet architecture and China's own planning traditions (see Figure 2).

Figure 2 A small district layout. Source: Hoa (1981).
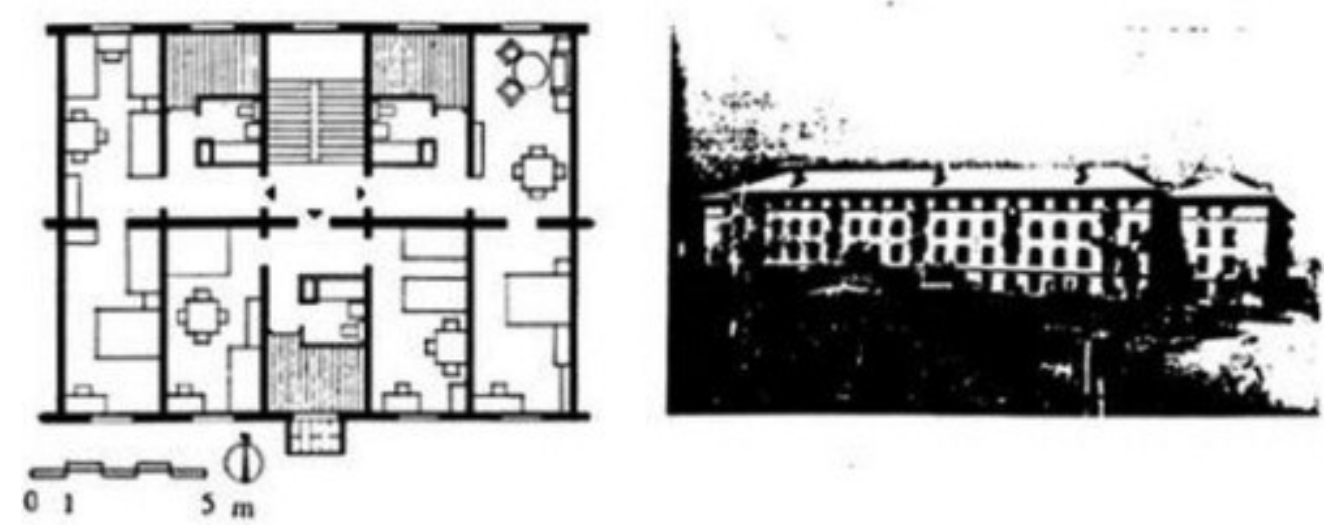

The Western influence came largely through the work of such as Ebenezer Howard, Clarence Perry and Lewis Mumford. These architectural thinkers had already had influence in Japan and their ideas were imported into China via Professor Uchida Yoshikazu of Tokyo, who advised on the re-development of Datong city in 1938. His team produced a plan in which each neighbourhood was designed to be around 0.8 square kilometres, consisting of 1000 households, and centred around a primary school and an adjacent park (Lu 2006, 25). Following the devastation that resulted from the Sino-Japanese war, especially in Shanghai, neighbourhood unit ideas, imported largely from America, were employed with even greater vigour. However, as Lu attests, it is ultimately difficult to draw firm conclusions as to exactly how much influence such Western forms had on urban planning, as China had its own history of creating areas that could be perceived as neighbourhoods, in the form of 'wards', from the 11th century onwards (Lu 2006, 25).

In addition, small districts brought in during the Mao era were based on the Soviet versionthe mikrorayon, or superblock schema, which organised housing around workplaces (Lu 2006, 20). In the Chinese context, this is known as the 'work unit' (danwei) and both Lu (2006) and, more forcibly, Bray (2005) argue that current-day small districts still bear a strong resemblance to these. Work units were part of the Maoist push towards collectivisation, typically housing people who worked together in shared dormitories and feeding them in shared canteens. They were also the principal method of implementing party policy in Maoist China, binding workers to them for life, providing housing, food, clinics, childcare, schools, and therefore identity, social respectability and socially important 'face' 
(mianzi) too. 'Face', perhaps best loosely translated as 'dignity' or 'prestige' is given and gained through one's behaviour in everyday and professional situations being calm and complimentary to others. Because work units provided all that was necessary for daily survival, they are often connected to the notion of the social guarantee or 'iron rice bowl' 10 (tiefanwan). Furthermore, the work unit not only provided a means to produce goods, but also, due to the close-knit nature of its community, a means to maintain a steady supply of political intensity and therefore activists who could be mobilised for party campaigns (Dutton $2005,164)$. This combination of producing tangible commodities alongside political fervour suggests that the work units were creating what Boris Arvatov ([1925] 1997) calls 'socialist' objects-objects that contained socialist ideologies within them. Therefore, a shared work unit experience was often a very powerful factor in people's lives, both during and after Mao's reign, and those people who set up businesses together after the work units had been largely dissolved had long-standing relationships built on high levels of trust. Indeed, Tsai (2002, 176-177) argues that contemporary workers' abilities to overcome common grievances are frequently enhanced due to collective action, which comes about as a result of their shared work unit in the past.

To some extent then, the small district in its built form can be understood as a revolutionary assemblage. In fact, the commercial developers of the current small districts often focus on creating spaces that lend themselves to the creation of neighbourhood connections and networks (linli guanxi 11) that are remarkably similar to those that work units once provided, proving just how deeply the ideological remnants of the work unit are ingrained in current practice - the 'mimetic effect' that Bray mentions $(2005,156)$. However, it must also be acknowledged that the very form of the work unit can be traced back to the traditional courtyard house that was designed to complement the ethical codes of Confucianism which underlines the fact that these also had very traditional Chinese cultural roots alongside revolutionary ones. In recognising these layers of historical influence, the built form of the work unit is best understood as being first re-appropriated by socialism, and only then by market socialism (Bray 2005, 35). Thus, small districts are based on the inescapable influence of the work unit as a built form in Chinese culture, but they also ought to be recognised as containing influences from both Western neighbourhood models and radical Soviet architectural forms, as well as much older Confucian models. This points to the fact that the small district is a complicated assemblage of historical forms and meanings, encompassing attributes of Confucianism, Westernism, and Maoism.

Unlike in other Chinese cities, where the replacement of work units by small districts has meant the removal of labour as the determinant of social space (Bray 2005), in Yiwu small districts remain linked to workplaces. Space, in this sense, is strictly divided according to manufacturing style, and the whereabouts of everyday life is dictated by what type of article individuals make. For example, Yangguang small district is close to Binwang market, and is therefore mainly home to those workers associated with the manufacture and trade of small craft and jewellery. This is a consequence of the fact that Yiwu did not become a manufacturing city or a place built from the profits of manufacturing. Instead, it was created as a place in which to manufacture, which resulted in departmentalisation to be ordered by labour from the onset. As a result, in Yiwu, labour relations continue to determine residential organisation and therefore, to a potentially greater extent, identity itself.

\section{Understanding Yiwu's sense of place as a post-revolutionary assemblage}

As Arefi (1999) notes, discussions of place in the 1980s and 1990s tended to be characterised by a 'narrative of loss', typified by the work of Marc Augé and his notion of the post-modern 'non-place' (the airport, motorway, or supermarket) that he contrasted with 'anthropological place' in which people all share the same set of social references and feel a joint identity (Augé 1995). Since then, various thinkers have created conceptualisations of place which run counter to Augé's understanding of place/non-place. Notable amongst these is Doreen Massey's $(1991,2005)$ argument that this conceptualisation tends to be self- 
enclosing, defensive and not 'adequate to this era of time-space compression' (1991, 24). Massey's concern is to acknowledge the need for a sense of fixed and secure identity within the flux of globalisation, but to disavow this of its reactionary potential by providing a reconceptualisation of place as unbounded and 'articulated moments in networks of social relations' $(1991,27)$.

In the Chinese context, Feuchtwang's (2004) work presents a particularly effective refuting of Augé's understanding of place. Feuchtwang argues that deterritorialisation can occur as a result of state or capitalist projects, but that reterritorialisation is always occurring and always has potential to occur. He acknowledges a relationship between globalisation and deterritorialisation, as global processes create change within previously less fluid environments but argues against positing the 'small scale' of anthropological place (such as that drawn upon by Augé), against the global scale. Instead, he insists that thinking on the matter of place should operate at a scale in between the extremes of the small and the global, as well as at these extremes (2004, 3-5). In doing so, like Massey he is conceptualising place as less bounded, more fluid and more defined by network relations of people and things.

Along these lines, recent debates in City have attempted to conceptualise cities as assemblages - processes of the gathering together of human and non-human elements as assemblages. In this understanding, cities are generated in the material and lived practices of daily life, often 'rigged together from whatever is at hand' (Simone 2011, 355). As McFarlane (2011) also points out, conceptualising cities as assemblages introduces a distributed concept of agency that extends conventional understandings of human agency by insisting that 'things' (infrastructure, housing, money, commodities, etc.) also matter. McFarlane's argument is that the materiality of the city is not simply a passive background to urban life, but that it actively shapes urban life.12 Such conceptualisations of cities are most useful in analysing how a sense of place in Yiwu is gained, particularly through its place in China's economic history due to its use of the Wenzhou model, and through the amalgamation of historical influences that can be perceived in its urban planning.

Defined as it is through the Wenzhou model, Yiwu owes much to its temporal elements-it is often defined by the number of commodities produced and sold every hour, the quantity of containers that leave every day or the sheer number of deals brokered within its markets. And while the city authorities are keen to promote Yiwu as a nice place to live and a physical site of incredibly fast-paced activity, they also cannot help promote it as time-as an astounding temporal phenomenon in which one lives the speed of commodity exchange as part of one's sense of place. In his classic Space and Place, Tuan (1977) acknowledges the tendency to promote temporal aspects when talking of how certain places are promoted in more 'abstract' ways-the endorsement of certain cities as places of great efficiency and exciting hubs of activity. As Tuan argues, these methods often tend to belong to cities which are either literally newly built or 'new' in their current form:

'An old city has a rich store of facts on which successive generations of citizens can draw to sustain and re-create their image of place ... New cities ... lacked a venerable past; to attract business and gain pride ... the emphasis tended to be on abstract and geometrical excellences such as 'the most central', 'the biggest', 'the fastest', and 'the tallest'.' (Tuan 1977, 174)

True to this description, in Yiwu, it is the impressiveness of speed and efficiency that are often marketed as defining features. However, Yiwu should not be perceived as a 'nonplace' simply because 'what reigns there is actuality, the urgency of the present moment' (Augé 1995, 104). The presence of speed and efficiency do not disenable a sense of place in Yiwu; rather, the promotion of these factors is part of a wider promotion of the efficiency of manufacturing. Such strategies and discourses resonate with current generations of 
manufacturers as part of a historical awareness of the varying acceptance of commercialism in China, and the nation's current status as 'the world's factory'. In fact, Yiwu's aims, ensconced as they are in the rationale of production and distribution efficiency via the Wenzhou model, reflect the ancestral links of many of its inhabitants, whose family originated from Wenzhou. In doing so, such aims create a sense of place through historical awareness of the role of Wenzhou in the economic history of China. This remains true, despite the way in which the Wenzhou model has had to battle for recognition and is now shaped to the requirements of market socialism, Western business interests and China's own domestic concerns around the way it is perceived globally. In addition, Yiwu's aims create a sense of place in the city despite the fact that Yiwu was not the original geographic site of the Wenzhou model-its history being initially tied to a specific group of people from a specific district and the roots of the Wenzhou model being effectively transported to the Yiwu that was set up in the late twentieth century. The inhabitants of Yiwu experience a lived environment in which history on the whole consists of replicas of past China, and is therefore something of an abstraction, a series of 'blips' in time that the Yiwu authorities attempt to join together via official promotional materials and architectural references.

However, despite this assemblage of history, place is created in Yiwu by a growing sense of the city being the site of the economic paradigm that has driven China's success and as a key site of 'Made in China'. Indeed, it may even be the case that, contrary to the beliefs of many economic commentators (e.g. Huang 2008), China does not lack a global brand as such-'Made in China' is quite clearly something of a brand. Of course, whilst it cannot be assessed economically alongside company brands, the cultural and psycho-social status of these three words being engraved on so many of the world's products bears an uncanny resemblance to other 'brand identities', providing clear opportunities for consumers to gain awareness of its connotations and even feel a fondness or 'brand affinity'. This occurs despite the connotations of its low-end produce, in much the same way that some have fondly dubbed Primark 'Primarni', in a sarcastic but somehow touching nod to an assumed difference in quality with Armani. In fact, 'Made in China' has done what 'Made in Spain' in the 1970s never quite managed to achieve: it is not an embarrassed apology for low-end products, but rather a triumphant celebration of use value at a bargain price-and Yiwu is its chief protagonist. This is reflected by the way in which manufacturers appeal to the potency of the name when attempting to close a deal with a wholesale buyer, emphasising how Yiwu offers the best value production in the world. For example, manufacturers often drew upon the place-ship and kudos of Yiwu as a tool to convince wholesale buyers that they were getting a good deal. According to one buyer, 'if they thought they were losing me, you know, if they thought I was about to walk away, they would start to tell me how this was Yiwu and I wouldn't do any better anywhere than this. They would say how efficient and fast it was, and how cheap, and how this was the world-famous Yiwu ... you know ... YIWU! ... and it didn't get better than this.'

It is also worth considering that Yiwu's growing self-awareness of its role in China's economic history, may well mean that its sense of place further develops over time, as it starts to become seen as typical of a specific era in China's history-one in which it has attempted to marry market economics and socialism. The awareness of the place that Yiwu is likely to occupy in future histories can be seen in the comments of some wholesalers who had relocated to Yiwu and who still struggled to feel that it was 'home' for them before realising its global place: 'I started to see it becoming well-known ... I felt different. I realized it was becoming famous, you know, globally, and all of a sudden, I felt proud.' As Augé admits, markets too can gain history: 'whether they are shrinking or expanding, the space in which they grow or regress is a historical space' (Augé 1995, 59). It may be that in the future, Yiwu's markets are hailed as the instigators of new forms of capitalist relations, in a manner not dissimilar to the way in which Venice's markets are regarded as the birthplace of Western capitalisms. Visiting Yiwu may then become part of what Augé describes as 'a turning back on the self' (Augé 1995, 92), an awareness of oneself as part of a 
geographically located spectacle, created as a result of mythmaking surrounding a specific place that causes its image to be stronger than the place itself. It is certainly tempting to suggest that in Yiwu the market is becoming accepted as place and that this is not a case of the purely economic realm being accepted as place, but rather of the assertion of politics existing within the economic realm. The corporate nature of the market in Yiwu is underplayed and interspliced with personal histories and ways of operating from the work unit days, as well as a long history of struggle for the Wenzhou model. These histories are reflected in the architecture and planning models used in the creation of small districts, the unintended aspects of both Confucianism and Maoism that enter into its on-going development, and therefore the fabric of its everyday spaces.

In its existence as a post-revolutionary assemblage, Yiwu's history is not historical for its residents in a simplistic way. Rather, their own pasts are somehow captured in both its economic mode of operation and its built forms. The Wenzhou model, having survived through Confucian, Maoist and reform-era times, transgresses simplistic definitions of the revolutionary and post-revolutionary. While it may be seen as most definitely reform-era for many of China's residents, this is not necessarily the case for Yiwu's inhabitants, or indeed any citizen with a tangible personal attachment to Wenzhou. In fact, Yiwu provides a good example of the more complicated subjectivities that exist in current-day China-its spatial relations force a nuanced analysis of the often unquestioned assumption that the shift from 'work unit person' (danwei ren) to 'social person' (shehui ren) corresponds unproblematically to the rise of the market and the privileging of individual interest.13 In reality, as Yiwu demonstrates, subjectivities can be created through the constant re-appropriation of deeply ingrained features from the 'old China', and their subsequent re-arrangement as part of the 'new China' (see Figure 3). For example, the comments of many manufacturers praise the way in which there is a 'collective mentality' in Yiwu-traditionally a feature associated with the pre-Deng era. One explained how deciding to switch from producing one product as opposed to another can be quite fast and spontaneous in Yiwu because it has to keep up with the latest product demand if it is to survive. In switching production, the respondent explained, 'you might start making a product very similar to someone else', but the other producer would not mind as they themselves would probably be switching production in a few months anyway. 'If everyone is just jumping on the next hot product, it doesn't matter if we sometimes make what someone else is making ... we still all survive as a result of being able to be spontaneous and follow demand.'

Figure 3 The Da'ansi Pagoda_'old China'_framed against tower blocks—'new China'. Photo: author's own. 


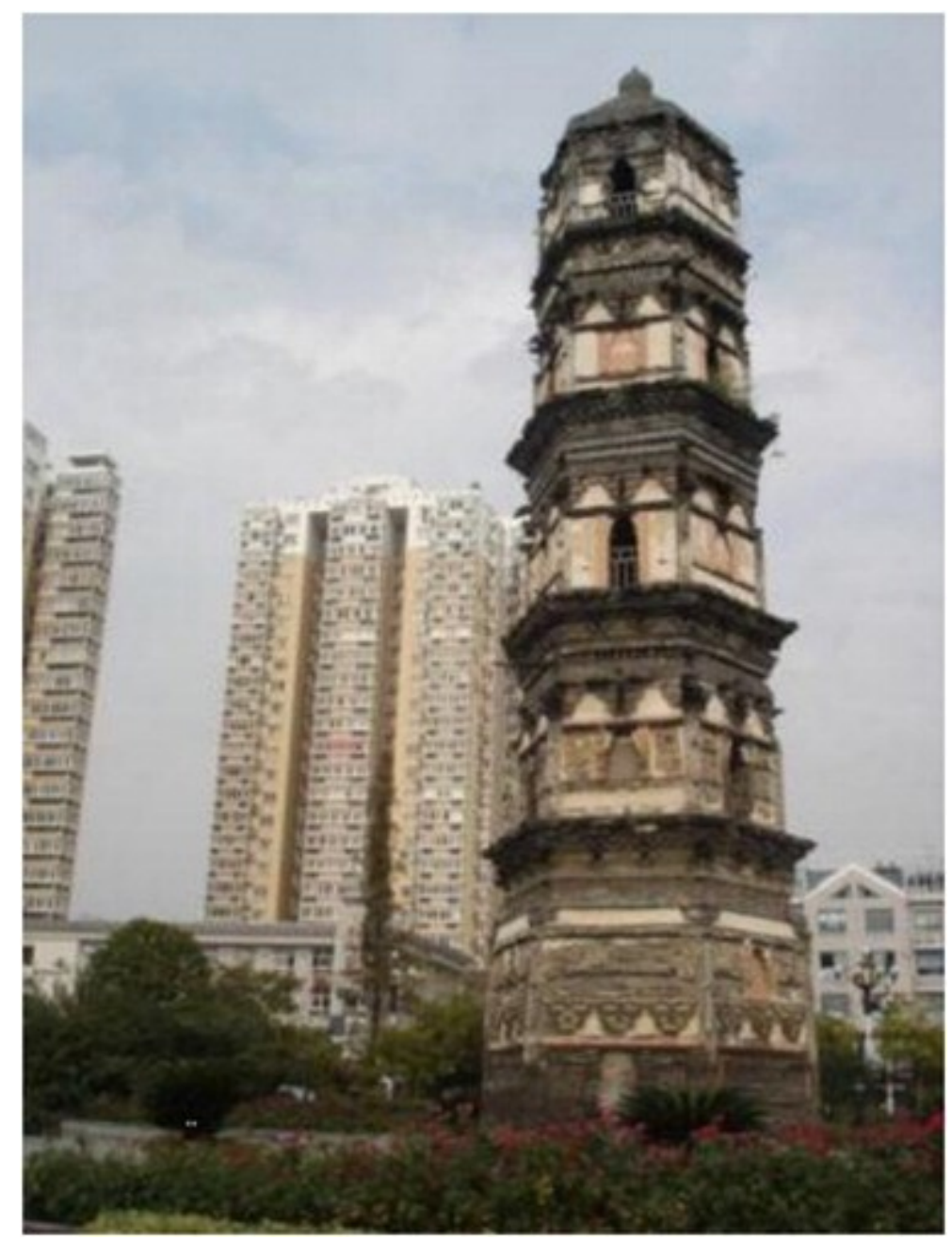

Such complications in attitudes and behaviour tend to obscure the neat lines between revolutionary and post-revolutionary subjectivity drawn up by thinkers such as Tang (2002). For Tang, revolutionary features such as content, use value, communal action, production and romanticism can be directly contrasted to the post-revolutionary features of form, exchange value, individualism, consumption, and pragmatism $(2002,128)$. Whilst Tang's charting of such features is useful in certain contexts, and of course embodies an overall truth, Yiwu's assemblage of features do not fit its parameters in a straight-forward manner. This is not to say Yiwu is not post-revolutionary of course; but rather to argue that it is not post-revolutionary in an easily map-able way, or in the way that contemporary commentators have tended to understand the word.

\section{Concluding thoughts}

The city of Yiwu has emerged as an unusual assemblage of elements that are combining to create something of a post-revolutionary sense of place. Its overlapping historical influences span back to dynastic times. Its story is that of an economic formula that was at first castigated, and then revered, promoted and transported to territories far from its own. Thus, history in Yiwu is embedded through a series of what might be called historical remnants of cultural forms, and philosophically through its use of a specific commercial model. This history is not based on the presence of a unified collective memory in a certain place having special significance. Rather, it is about a fluid mix of past and present cultural elements that do not necessarily make logical sense together, but that forge an identity that speaks to the 
contradictions inherent in post-revolutionary China. In fact, the strength of place in Yiwu is all about its ability to understand, contextualise, and negotiate these contradictions.

When viewed as an assemblage, it becomes easy to explain how Yiwu has gained a sense of place. Indeed, via the assemblages of historical factors at play in its economic organisation and built environment, and specifically due to the ways in which these factors play out amongst residents, Yiwu has a greater sense of place than can be understood at first glance. The burgeoning sense of place there has arisen precisely because of the unusual assemblage of those historical and tangible elements that were discussed in this article-the resurgence of the Wenzhou model, the site of a post-revolutionary heroic effort towards economic development, the persistence of built forms that hold echoes from both the Maoist and the Confucian past. Furthermore, the potency of this assemblage of elements forces a new way of perceiving place-one which is less tied to the traditional notion of place as geographically bounded and based on collective memory, and much more akin to Massey's 'articulated moments in networks of social relations' $(1991,27)$, moments that resonate with the current lived experiences of the post-revolutionary subject.

In fact, Yiwu may well provide an example of the kind of place-making that Massey called for, acknowledging the need for some kind of stability, whilst precisely avoiding the reactionary. It is perhaps a fine example of how Massey's 'progressive' conception of place works when applied to a specific location. It is most certainly defined by its social interactions; its boundaries are ever-changing as its success causes it to expand and even be transported into other national territories; its heritage encompasses dynastic, Maoist, and market traditions; and its specificity certainly does not arise from a long-internalised history. Indeed, the promotional websites attempt to promote such a history, failing perhaps to see that Yiwu does not need this in order to have a sense of 'place'. It holds, in its complicated fluidity, an undeniable sense of place, which effectively denies the reactionary definition of place, proving the validity of Massey's progressive conception of place.

\section{Notes}

1 The YRD economic zone refers to 28 cities across Jiangsu, Anhui and Zhejiang provinces. It is dominated by Shanghai and its vast interior is heavily industrialized with an advanced transport infrastructure that includes road, rail, air and ports.

2 All these figures can be found at http://www.yiwu-market.cn/About\%20yiwu.htm.

3 It should be noted that throughout the article there are a few terms that are difficult to translate as they are bound in nuanced cultural understandings in the Chinese context. Whilst aware of the loss incurred in translation, these appear in the English with an initial explanation of their Chinese meaning, and their pinyin translation.

4 Celebrity businessman Jack Ma (who stars in Win in China - China's version of the TV show The Apprentice) is the founder of the ali group of companies, which includes the business-to-business website alibaba.com. It is his belief that the future will be based on small to medium sized enterprises (shrimps), rather than large corporations (whales), and this has informed his highly successful business models.

5 Technically neo-Confucianism began in the Tang (772-841) dynasty when Han Yu and Li Ao strove to empty it of its more mystical elements that had come from Buddhism and Daoism and place emphasis on the creation of rules for an ethical life. It became prominent during the Song and Ming dynasties.

6 This is the logic proposed and promoted by Deng in his famous speech often characterised with the words 'to get rich is glorious'. 
7 For a more detailed account of how Deng Xiao-ping managed to gain acceptance for his policies through respecting Mao's legacy and re-appropriating Confucian ideals, see Vogel (2011).

8 This 'cleansing' was most dramatically put into action with the razing of Zhejiangcun in Beijing, in 1995 a manufacturing area comprised of the largest collection of migrants in any Chinese city. Located in the Fengtai district in the south of Beijing it had grown from just six families in 1984 to a population of over 100,000 (see Li Zhang 2001; Xiang 2005).

9 The city of Datong is typical here; its Mayor determinedly razing thousands of hutong homes in order to rebuild the 14th century Ming dynasty defensive wall to create a city that feels ancient and will attract tourists. The redevelopment of Datong is detailed in director Hao Zhou's 2015 documentary film The Chinese Mayor in which Mayor Geng Tanbo grants access to his political life, displaying his ambitious plans to rid the city of pollution and create economic opportunities precisely by making it visitable.

10 The notion of the 'iron rice bowl' relates to the idea of welfare provision being solid and unbreakable, as it was deemed to be under Mao.

11 Guanxi is often translated as 'relationship' or 'connection', but is best explained as a combination of ganqing (depth of feeling within an interpersonal relationship), and renqing (moral obligation and 'face' or social prestige). It describes personal relationships in which one is able and obliged to perform and receive favours - a long-term, obligated and heartfelt connection, in which individuals have the right to demand fair return, benefits sharing and reciprocity.

12 Brenner, Madden, and Wachsmuth (2011) critique this stance, arguing that the danger of assemblage thinking is that it downplays the 'context of contexts' and this fails to acknowledge the ways in which capitalism shapes contemporary urbanisation. Building on this, Simone (2011) argues that whilst the 'contexts of contexts' is important, capitalist logics do not provide exhaustive accounts of urban sites and practices of urbanisation.

13 See Cao and Zhongya [1997] who put forward a relatively straight-forward connection between the onset of market economics and the rise of non-collective, i.e. individualistic, identities.

\section{REFERENCES}

Arefi, Mahyar. 1999. "Non-Place and Placelessness as Narratives of Loss: Rethinking the Notion of Place." Journal of Urban Design 4 (2): 179-193.

Arvatov, Boris. [1925] 1997. "Everyday Life and the Culture of the Thing (Towards a Formulation of the Question)." October 81: 119-128.

Augé, Marc. 1995. Non-Places: Introduction to an Anthropology of Supermodernity. London: Verso.

Bray, David. 2005. Social Space and Governance in Urban China. Stanford, CA: Stanford University Press.

Brenner, Neil, et al. 2011. "Assemblage Urbanism and the Challenges of Critical Urban Theory." City 15 (2): 225-240.

Cao, Jinqing, and Zhongya Chen. 1997. Leaving the Ideal Castle: Research on China's Danwei Phenomenon. Shenzhen: Haitian Press. 
Chen, Zhengxing. 2000. "The Rise and Development of Yiwu's Small-Commodities Market." City 33 (5): 65-76.

Dicks, Bella. 2004. Culture On Display: The Production of Contemporary Visitability. London: McGraw-Hill Education.

Dutton, Michael. 2005. Policing Chinese Politics. Durham, NC: Duke University Press. . Feuchtwang, Stephan. 2004. Making Place: State Projects, Globalisation and Local Responses in China. London: Routledge.

Hoa, Léon. 1981. Reconstruire la Chine: Trente Ans d'Urbanisme 1949-1979. Paris: Editions du Moniteur.

Huang, Yasheng. 2008. Capitalism with Chinese Characteristics: Entrepreneurship and the State. New York: Cambridge University Press.

Jung, Kim. 2014. "Making Cities Global: The New City Development of Songdo, Yujiapu and Lingang." Planning Perspectives 29 (3): 329-356.

Kendall, Paul. 2015. "Between Big City and Authentic Village." City 19 (5): 665-680. . Liu, Alan. 1992. "The Wenzhou Model of Development and China's Modernization." Asian Survey 32 (4): 696-711.

Lu, Duanfang. 2006. Remaking Chinese Urban Form: Modernity, Scarcity and Space, 19492005. Abingdon: Routledge.

Massey, Doreen. 1991. “A Global Sense of Place.” Marxism Today June: 24-29.

Massey, Doreen. 2005. For Space. London: Sage Publications.

McFarlane, Colin. 2011. “Assemblage and Critical Urbanism.” City 15 (2): 204-224.

Roy, Ananya, and Ong Aihwa, eds. 2011. Wording Cities. West Sussex: Wiley-Blackwell.

Simone, AbdouMaliq. 2011. "The Surfacing of Urban Life." City 15 (3-4): 355-364.

Tang, Xiaobing. 2002. "The Anxiety of Everyday Life in Post-Revolutionary China." In The Everyday Life Reader, edited by Ben Highmore, 125-138. London: Routledge.

Tsai, Kellee S. 2002. Back-Alley Banking: Private Entrepreneurs in China. London: Cornell.

Tuan, Yi-Fu. 1977. Space and Place. Minneapolis: University of Minnesota.

Vogel, Ezra. 2011. Deng Xiaoping and the Transformation of China. New York: Harvard.

Xiang, Biao. 2005. Transcending Boundaries: Zhejiangcun: The Story of a Migrant Village in Beijing. Leiden: Brill.

Yu, Jianxing, Jun Zhou, and Hua Jiang. 2012. A Path for Chinese Civil Society: A Case Study on Indsurtial Associations in Wenzhou China. New York: Lexington Books.

Zhang, Li. 2001. Strangers in the City: Reconfigurations of Space, Power, and Social Networks Within China's Floating Population. Stanford, CA: Stanford University Press. 